\title{
A New Advanced Graduate Course for Developing and Challenging World
}

\author{
Zheng (Jeremy) Li
}

University of Bridgeport, Bridgeport, CT 06604, USA

\begin{abstract}
The fast developing engineering technology and globalization process have changed traditional educational roles and expectations from teachers. This leads to the course curriculum and teaching reforms that focus on introducing potential technologies and programs which can provide students with latest and challenging engineering knowledge. A recent graduate course titled "Manufacturing Strategy and Lean" has been developed to establish entrepreneurship opportunities for fast-pace and developing world. Some advanced technologies, including Failure Modes and Effects Analysis (FMEA), Standard Operation Procedure (SOP), and Lean Manufacturing, have been introduced in helping students to gain high level of engineering experiences. It also helps students to examine political, social and economic issues that associated to engineering project delivery processes that can lead to save product process expenses, increase manufacturing efficiency, improve product quality and shorten production period. Although this course was taught at mechanical and manufacturing engineering majors, it can also benefit the students from many other engineering disciplines such as industrial engineering, civil engineering, environmental engineering and engineering management. The fundamental theories and technologies taught in this class can be applied to most areas of US industrial and engineering practices.
\end{abstract}

Keywords Cost-Effective, Energy-Saving, Lean Manufacturing, FMEA, SOP

\section{Introduction}

Some students enrolling into the technological and engineering major might have the difficulty to choose an appropriate engineering discipline[1]. One of the good ways is to cover the disciplines to multidisciplinary engineering studies to provide them with fundamental concepts, implement real industrial case studies and gain feasible and potential solutions[2]. The explanation of how students and future engineers in different disciplines can contribute to the solution of the engineering issues could become the feasible ways of obtaining a general idea of what is the duty of engineers in each engineering discipline[3,4]. Related engineering case study from industry are good resources in the engineering classroom, and it can be applied to help students to understand the real issue and to show how the technical concept can be used in real cases[5].

The Lean Manufacturing focuses on preserving product values with less work to improve overall values for the customers. It leads the higher manufacturing efficiency and decreased waste production to reach the optimizing production flow. Lean Manufacturing can enhance organization's competitive capability including industrial material

* Corresponding author:

zhengli@bridgeport.edu (Zheng (Jeremy) Li)

Published online at http://journal.sapub.org/edu

Copyright (C) 2012 Scientific \& Academic Publishing. All Rights Reserved handling, inventory, quality, scheduling, personnel and customer satisfaction[6,7]. Lean Manufacturing can also keep the creation and maintenance of the manufacturing and production system that make high quality products repetitively. The Failure Model and Effects Analysis (FMEA) has been applied to some industries for years and implementation of this technology will save product process expenses, increase manufacturing efficiency, improve product quality and shorten production period which will enhance the company's competition in the market[8]. To understand the potential failures and effects in companies' daily production and manufacturing processes, several modeling and simulation tools will be used to help understanding the major factors that will affect the production, process efficiency, product quality and manufacturing quantity[9]. The FMEA is intended to document the following events:

(1). Event of failure

(2). Failure mode

(3). Failure effect

(4). Failure analysis with solution

The basic idea of FMEA is to spot risks and to initiate dedicated efforts to control or minimize the risks in firm's business and manufacturing processes. Knowing your risks can make the production and manufacturing process plan more realistic. FMEA seems to work best, when an engineering team documents its known knowledge about known cause- and effect-relationships. In this analysis mode, the timely sequence of failure events should be worked out first, 
before entering results into a FMEA sheet. The flow diagrams can be introduced to organize the items into a logical sequence of events and start with key functions the organization has to perform and then identify ways to deteriorate those key functions (modes and causes). It is not easy to anticipate the unknown risks and unknown failure mechanisms in manufacturing process and production. In this case, the methodology of Anticipatory Failure Determination will be recommended when you need to analyze subtle failure mechanisms or have to predict future failures from the manufacturing process and production. It is important and critical to stay well disciplined in cause-finding and effect-determining to gains strong FMEA's results.

With the implement of Standard Operation Procedures (SOP) and ISO 9001/ISO14000 standards, the plant performance in manufacturing flow, organizational functions, process control, metrics and logistics can be significantly improved.

The feedback from many students graduated and currently working in different industries indicated that all these advanced technical and engineering knowledge learnt from our class are important for their academic learning, career plan, job hunting, and stay success in today's challenging world. These techniques can also help industries to determine if their businesses are successful or not. It shows that, if we properly educate the students with the latest and important technologies early in the school, they can get ready to face the strong challenge when they plan their current academic study and future career.

\section{Case Study and Projects}

In addition to the theoretical fundamentals and lean manufacturing strategy, FMEA and other related advanced engineering technologies, several case studies from real engineering practices are discussed in the class to help students understand the concepts of these hot technologies. The thorough discussion on these real case studies helps students learn how the feasible manufacturing strategy planning and Lean Manufacturing solutions can improve the quality of engineering education in today's engineering school. Two of the class case studies of applying the Lean Manufacturing strategy and FMEA are as follows:

\section{Case study 1:}

The problem of one mechanical driver system has been recorded. To quickly find out the cause of problem and determine the efficient solution to solve the problem, the Table 1 summarizes the case study using standard procedures of Lean Manufacturing strategy and FMEA.

\section{Case study 2:}

The problem of one pressure vessel system has been reported. To efficiently verify the cause of problem and comes up the positive solution to resolve the problem, the Table 2 illustrates the case study detail by applying the standard procedures of Lean Manufacturing strategy and FMEA.
Table 1. Case study of problem in mechanical driver system using Lean and FMEA

\begin{tabular}{|c|c|}
\hline Function & $\begin{array}{c}\text { CAM shaft rotation to drive me- } \\
\text { chanical system }\end{array}$ \\
\hline Failure Mode & CAM follower is not rotating properly \\
\hline Effects & $\begin{array}{c}\text { Mechanical system is not working } \\
\text { continuously }\end{array}$ \\
\hline S(severity rating) & 8 \\
\hline Cause(s) & $\begin{array}{c}\text { The coupling for CAM shaft is not } \\
\text { secured properly }\end{array}$ \\
\hline O(occurrence rating) & 4 \\
\hline Current Controls & $\begin{array}{c}\text { Inspect the CAM coupling for proper } \\
\text { assembly to prevent the problem from } \\
\text { happening }\end{array}$ \\
\hline D(detection rating) & 3 \\
\hline CRIT(critical characteristic) & N \\
\hline RPN(risk priority number) & 96 \\
\hline Recommended actions & $\begin{array}{c}\text { Performing component and assembly } \\
\text { tolerance and structure analysis }\end{array}$ \\
\hline $\begin{array}{c}\text { Responsibility and target } \\
\text { completion date }\end{array}$ & Bob Lee 1-Aug-2010 \\
\hline Action taken & Completed \\
\hline
\end{tabular}

Table 2. Case study of problem in pressure vessel using Lean and FMEA

\begin{tabular}{|c|c|}
\hline Function & Fill liquids into the vessel \\
\hline Failure Mode & $\begin{array}{c}\text { Control pressure sensor is not working } \\
\text { properly }\end{array}$ \\
\hline Effects & Liquids spills on the plant floor \\
\hline S(severity rating) & 7 \\
\hline Cause(s) & $\begin{array}{l}\text { Pressure control sensor is not functioning } \\
\text { properly } \\
\text { Pressure sensor is not proper installed }\end{array}$ \\
\hline $\mathrm{O}$ (occurrence rating) & 3 \\
\hline Current Controls & $\begin{array}{l}\text { Set the time limit based on time to fill liquids } \\
\text { into pressure vessel } \\
\text { Set the pressure limit to trigger pressure } \\
\text { sensor when maximum liquid level reached }\end{array}$ \\
\hline $\mathrm{D}$ (detection rating) & 5 \\
\hline $\begin{array}{l}\text { CRIT(critical charac- } \\
\text { teristic) }\end{array}$ & $\mathrm{N}$ \\
\hline $\begin{array}{l}\text { RPN(risk priority } \\
\text { number) }\end{array}$ & 105 \\
\hline Recommended actions & $\begin{array}{l}\text { Set the pressure sensors: one at the top and } \\
\text { another at bottom pressure vessel } \\
\text { Inspect the pressure sensor connectivity }\end{array}$ \\
\hline $\begin{array}{l}\text { Responsibility and } \\
\text { target completion date }\end{array}$ & Cindy Berry, 18-May-2009 \\
\hline Action taken & Completed \\
\hline
\end{tabular}

Here, in the real case studies, all failure modes should be determined by students based on the functional requirements and its effects. A failure effect is assumed as the result of a failure mode on the systematic function confirmed by the users and it is necessary to summarize these effects in terms of what the users might report or experience. The failure effects might involve systematic malfunction, enlarged shock / vibration, or even injury to the users. Some important factors included in the above case studies can be described as follows:

1. Severity (S): The range of effect changes from 1 (no danger) to 10 most danger) that can help to determine the 
defect levels. If the severity of an effect is more than 9, immediate actions are required to modify the systematic design by avoiding the failure mode to protect users from the effect. Usually the severity numbers over 9 will lead significant problems or even cause injury to the users.

2. Occurrence $(\mathrm{O})$ : It is necessary to verify the cause of a failure and find out how often it can occur. This can be investigated by comparison to the failures of similar products and processes that have been previously documented. A failure cause represents the design or systematic weakness leading a failure mode should be determined and documented. The occurrence number of a failure mode changes from 1 to 10 . Necessary actions should be taken if $\mathrm{O}$ is larger than 4 in non safety failure mode or $\mathrm{O}$ is larger than 1 when $\mathrm{S}$ is larger than 9 .

3. Detection (D): The proper detection techniques should be used to verify the current systematic controls that can keep the failure modes from occurring or detect the failure before it reaches the customers. It is important to determine the appropriate testing, analysis, and monitoring methodologies that might be employed to verify the failures and determine how the failures are detected through the failure control technologies. The detection number is considered as the capability of planned tests to detect the failure modes.

4. Risk Priority Numbers: From the above three procedures, the Risk Priority Numbers (RPN) can be determined. RPN are the threshold values in the evaluation process. After numbers of severity, occurrence and detection being determined, the RPN can be calculated through $\mathrm{RPN}=\mathrm{S} \times \mathrm{O} \times \mathrm{D}$.

The procedure of Lean Manufacturing and FMEA should be observed for the whole project process. Once these procedures have been completed, it will be fairly easy to identify the areas of major concerns. The failure modes with higher RPN should be given the priority for correction or re-design action. Since there might be some cases with less severity but higher occurrences and lower detection, it is important to analyze the failure mode detail and understand that it is not always to first focus on the failure modes with highest RPN.

After the above failure mode numbers have been verified, the recommended corrections with objectives, control methodologies and dates of implementation should be proposed and documented. Once the proposed corrections have been done to the target design or process, the revised RPN should be verified again to confirm if the corrective actions lead the positive improvements. In case a design or a process changes later after FMEA has been done, an updated FMEA related to the change of design or process should be implemented. To improve the engineering process per Lean Manufacturing and FMEA procedure, the failure severity ought to be reduced, the failure occurrence should be minimized, and better failure detection techniques must be implemented.

Through this course learning and real case studies, the students will understand that, in industrial and engineering processes, Lean Manufacturing and FMEA technique can provide an efficient analytical approach while dealing with potential failure modes and their associated causes in engineering design and processes. When considering possible failures in a design or production process, such as safety, cost, performance, quality and reliability, the students and future engineers can gain many sharp and advanced information on how to change the development and manufacturing processes to prevent these failures from occurring as best as possible. Lean Manufacturing and FMEA introduce the efficient and easy tools to determine which risk has the greatest concern, and which corrective action is needed to prevent a problem before it arises. The development of these specifications will ensure the product to meet the required functions.

In addition to the above real case studies, several class formal projects that are simulated from today's U.S. successful companies are introduced and assigned to students to help them in their learning process to establish the industrial and engineering standards. One of the class projects is as follows:

One plant manager walked into the manufacturing department and noticed some defect products in the production line. He checked with manufacturing department manager and required him to determine what cause these product problems. The manufacturing department manager promised to correct these product defects. A few days later, the plant manager found similar defect products again in the same manufacturing department. Please use the Lean Manufacturing and FMEA techniques to help this firm to improve the production processes in this manufacturing department.

In order to help students learn how to resolve the above product defect problems, students will be divided to the several groups with different responsibilities: plant manager, manufacturing department manager, foreman, manufacturing engineer, QC personnel, technician for manufacturing setup, and operators. Each group is required to use the concepts of Lean Manufacturing and FMEA procedure learnt from the class to plan the manufacturing strategy and bring the positive improvement to this manufacturing department.

\section{Conclusions}

Today's fast-path developing and challenging world requires college students and future engineers to gain more advanced and professional engineering knowledge, in order to be successful in their current academic learning and future career planning. The teaching reform efforts in this paper focus on directly improving faculty teaching capability and student learning process to meet today's technological and engineering challenge. A new course, currently taught at the mechanical and manufacturing engineering majors, was designed to help our students in dealing with professional, engineering, and ethical issues associated with modern engineering practice. This new course places more emphasis on how to guide engineering students to gain necessary industrial and engineering knowledge which are usually missing from the current engineering course curriculum, including 
real and special case studies of Lean Manufacturing, FMEA, Six Sigma, ISO 9001 and ISO 14000. In addition to the numerous real industrial cases studies and discussions, a number of real projects have been developed in this course and assigned to students to help them properly apply the strategic skills learnt from the class. The students will be benefited from these class projects by interacting in a group environment with other multidisciplinary students. Finally, the students will learn about the industrial environment in this challenging world and come up with some feasible and sustainable solutions to the real industrial and engineering issues. All these hot and useful industrial knowledge, combined with traditional engineering technology taught in current MS engineering degree level, can help students in their current academic learning, soon job hunting process and future engineering career planning. The positive feedback from our many students confirmed this promising curriculum reform in this new engineering college course.

\section{REFERENCES}

[1] Kim, P., Miranda, T. and Olaciregui, C., 2008, "Pocket School: exploring mobile technology as a sustainable Literacy education option for underserved indigenous children in Latin America", International Journal of Educational Development 28 (4), p. 435-445.
[2] Grossman, G., Onkol P. and Sands, M., 2007, "Curriculum reform in Turkish teacher education: attitudes of teacher educators towards change in an EU candidate nation", International Journal of Educational Development 27, p. 139-150.

[3] Kubow, P. and Fossum, P., 2007, "Comparative Education: Exploring Issues in International Context", Pearson Education/ Merrill Prentice Hall, ESBN"

[4] Masemann, V., Bray, M. and Manzon, M, 2007, "Common Interests, Uncommon Goals: Histories of the World Council of Comparative Education Societies and its Members, Comparative Education Research Centre", The University of Hong Kong, Hong Kong,

[5] Bray, M., Adamson, B. and Mason, M., 2007, "Comparative Education Research: Approaches and Methods. CERC Studies in Comparative Education", vol. 19, Comparative Education Research Centre, The University of Hong Kong, Hong Kong, 2007.

[6] D. Phillips and M. Schweisfurth, "Comparative and International Education: An Introduction to Theory, Method and Practice", Continuum, London 2006.

[7] A. Aypay, "Re-structuring higher education: the influence of socio-economic and political environments to institutional adaptation of Universities”, Eğitim Yönetimi 34, pp. 194-213, 2003.

[8] Okcabol, R., "Teacher qualifications and the new council of higher education model", II. Ulusal Öğretmen Yetiştirme Sempozyumu, 10-12 Mayıs, Çanakkale, Turkey, pp. 419-425, 2000. 